\title{
CYP2D6*17 Allele
}

National Cancer Institute

\section{Source}

National Cancer Institute. CYP2D6*17 Allele. NCI Thesaurus. Code C45618.

Human CYP2D6*17 allele is located in the vicinity of 22q13.1 and is approximately $4 \mathrm{~kb}$ in length. This allele, a variant form of the CYP2D6 wild-type allele, encodes cytochrome P450 2D6*17 protein. The CYP2D6*17 allele exhibits two clinically-relevant SNPS (g.1023C > T, g.2850C > T) that result in coding changes (T 107I, R296C). These alterations decrease the enzymatic activity of the cytochrome P450 2D6*17 protein. 